\title{
Underlying Meanings of the Hitler Metaphor in Western Media
}

\section{Eugenia Kuznetsova*}

Department of Social and Human Sciences, Institute of Human Rights, Spain

\begin{abstract}
The present research aims to analyse the metaphorical use of Hitler's personality in the Russian context in contemporary mass media published in English. The brief analysis of the metaphor's use was also conducted for media published in German and Spanish. The research encompasses 13 years, from May $1^{\text {st }} 2001$ to May $1^{\text {st }} 2014$. The first part of the research deals with the dynamics and frequency of the metaphor's use, exposing the growing popularity of the Hitler metaphor in shaping the ideology of contemporary Russia in media discourse. The second part includes a critical metaphor analysis that involves 268 articles from The Times (UK), 176 articles from The Wall Street Journal (USA) and 265 articles from Die Welt (Germany) in the time range from May $1^{\text {st }} 2001$ to May $25^{\text {th }}$ 2014. The analysis attempts to discover the underlying meanings of the Hitler metaphor and identify the purposes and ideologies conveyed by this particular metaphor.
\end{abstract}

Keywords: Metaphor; Mass media; Critical metaphor analysis; Linguistic analysis

\section{Metaphor and Media}

The media is a powerful tool for communication which influences national identity, defines the boundaries of cultural identities [1], is able to produce social aggression [2], reinforces the pre-existing attitudes and behaviours of the audience [3], constructs an authoritative public voice, asserts interpretive frames [4] and influences preferences, opinions and judgements [5]. Donald Matheson, analysing media discourse, explains that the news does not simply reflect the world as if it were a mirror (as journalists often claim). Nor does the news construct a picture of reality, as critics suggest. Instead "news makes sense within a social context: if it acts all as a mirror, it reflects preoccupations within that society, and when it constructs a picture of the world, the picture is often very close to what members of that society already know" [6]. Moreover "reporting foreign news in general can say as much about the reporters and their social, political, cultural, historic, practical, technical contexts as about the reported" [7]. Taking into account these assumptions, the present article aims to answer the following research questions:

How often is Putin compared to Hitler in press published in English? What are the contexts of Hitler-Putin comparisons? What are the dynamics of these analogies in the mass media? Which events during the investigated period correlate with Hitler-Putin comparisons? What are the underlying meanings of the analysed metaphor? What assumptions are implied in the analysed metaphor in media discourse?

Answering these questions we can go beyond the basic view on Hitler metaphor and based on qualitative and quantitative data illustrate how the frequency and context of inclusion of a particular metaphor can frame the image of a country and its leader. The research contributes to the understanding of the media shaping of the Russian leader and the place of Russia within contemporary system of international relations. Comparing Putin to Hitler can also say much about Western anxieties and attitudes; this metaphor not only shapes a new image of Putin, but also refers to pre-existing social fears in the Western world. Analysis of the metaphor can also show whether media follow the official policy of the European Union and USA regarding tensions between Russia and Ukraine.

The methodology of the research is based on a critical metaphor analysis that includes cognitive processing of metaphors [8]. The discourse model known as critical analysis of metaphors includes analysis of rhetorical and ideological role of Hitler metaphor in political discourse, focusing on authentic data. First we identified which metaphors would be chosen, having decided to analyse the conceptual metaphor of Hitler in the context of the personality of Vladimir Putin and contemporary Russia. Thus we limited the research to one particular metaphor that forms the entire metaphorical system, including not just the comparison with the historical figure of Adolf Hitler, but also the drawing of parallels between different aspects of life in 1930s Germany and contemporary Russia. The research was conducted in several stages:

1. Contextual analysis, when the research questions were developed and the corpus for the analysis identified;

2. Metaphor identification-the Putin-Hitler metaphor was identified and treated as conceptual;

3. Metaphor interpretation-the conceptual metaphor was analysed individually and in interaction with other features of text and other language choices;

4. Metaphor explanation-we attempted to explain the metaphor's application in the broader political context and define underlying meanings (Figure 1).

Comparing Putin to Hitler is not just a journalistic tool utilised to draw the attention of the audience; it is an attempt to explain one concept (in this case a personality) in terms of another, well-known concept (another well-known personality) and this tool is no more than a metaphor. Metaphor, which comes from metaphorein-(transfer or transport), in this case transfers Putin's behaviour models and

*Corresponding author: Eugenia Kuznetsova, Department of Social and Human Sciences, Institute of Human Rights, Spain, Tel: +34-944-139-000 E-mail: eugenia.kuznetsova@deusto.es

Received September 09, 2014; Accepted October 20, 2014; Published October 26, 2014

Citation: Kuznetsova E (2014) Underlying Meanings of the Hitler Metaphor in Western Media. J Mass Communicat Journalism 4: 230. doi:10.4172/21657912.1000230

Copyright: $\odot 2014$ Kuznetsova E. This is an open-access article distributed under the terms of the Creative Commons Attribution License, which permits unrestricted use, distribution, and reproduction in any medium, provided the original author and source are credited. 


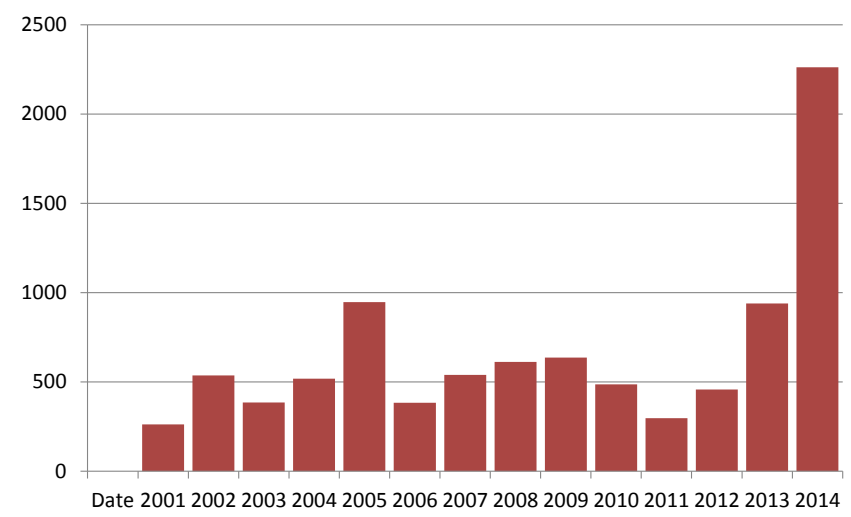

Figure 1: Putin and Hitler mentions yearly distribution in English press: 01 May 2001-01 May 2014 (Data source: Factiva Database).

processes occurring in contemporary Russia back in history to before the beginning of World War Two when the world watched the new Germany arising in Europe. In most discourses (political, social or media discourses) Hitler cannot be treated as just a historical figure; if anyone claims that someone else is behaving like Hitler it always has an extremely negative connotation, as Hitler is an indisputably negative figure and metaphorically often serves as an embodiment of evil. Thus, when Putin is compared to Hitler he is put on the side of world evil.

The metaphor is more of a cultural frame than a linguistic device [9]. If we see the metaphor as a "pattern of neural connections across domains" [9], which evokes certain knowledge, we are able to discover a new layer of meaning in the text. Comparing Putin to Hitler is not a pure comparison where we compare something to a well-known thing or concept to aid understanding. I consider this comparison to be a conceptual metaphor that consists of two conceptual domains where one is understood in terms of the other [10]. Putin is Hitler is a conceptual metaphor where Putin is a target domain and Hitler is a source domain. The source domain in this case is the vehicle that transports meaning to the audience [11] and the target domain is a subject to conceptualisation. Metaphor in media discourse is believed to instantiate cultural models of the world we live in by being a powerful communicative and conceptual tool $[12,13]$; it transfers conceptual meaning [14] and transmits new knowledge and ideas [15]. Metaphor is also a powerful tool in international politics-by tracing some of the ways in which different political actors use metaphor it is possible to obtain surprising perspectives on the nature of transnational political discourse [16]. Paul A Chilton, analysing the post-war world, names metaphor a heuristic device to conceptualise a policy to fit the postwar uncertainties. In the case of conceptualising the behaviour of Putin as "hitlery", the media responds to social uncertainties about energy dependency and nuclear threats from contemporary Russia, which does not seem to follow the path of the democratic doctrine. Metaphors are a contributing factor in the production, reproduction and contestation of political realities, including the realities of international politics [16]. They also reflect and construct meaning and are part of the political struggle for collective meaning [17]. Metaphors provide "the framework for conceptualizing political strategies" [18] and if Western governments decide to restrain the Russian Federation with the help of economic or political sanctions the mass media assists in conceptualising this political strategy, defining Putin as a political force that deserves the already applied and future sanctions. Russia has always played a central role in the destabilisation of common-sense news frames following the end of the Soviet Union [7] and today the
Western media has a new challenge: to frame the new Russia that since 2001 has slowly and gradually turned into a totalitarian-like state [19].

\section{Mass Media in English}

Media published in English were chosen for the research as the biggest segment of the mass media in the world. English press often defines the trends in coverage of main topics all over the globe. Many national press agencies also have English versions of their media, but most of the news and stories in this segment still originate from the United Kingdom and the United States as well as from Canada, Australia and New Zealand.

To approach the general topic of Vladimir Putin compared to Adolf Hitler and to see the frequency and dynamics of these comparisons in the mass media we checked the period of the last 14 years-generally almost all the years of Putin's rule in Russia (he was inaugurated on May 72000 and has ruled the country until today, if we do not take into account a 4 years break when formally he acted as Prime-Minister).

The initial results show that from May $1^{\text {st }} 2001$ to May $1^{\text {st }} 2014$ Hitler was mentioned in the context of Putin's actions or behaviour or in the context of Russia in general (including messages about the USSR's role in the Second World War) 13,039 times. In 5,836 items the surnames of Putin and Hitler were mentioned in the same paragraph and in 748 cases the surnames stood next to each other (less than two words between the surnames) in tokens such as: "Putin is Hitler", "Putin and Hitler", "Putin, like Hitler", "Like Putin, Hitler", "Putin=Hitler", "Putin uses Hitler's terminology", "Putin equals Hitler" and others. Another token that is mentioned 32 times is "Putler", a combined word made from the surnames Putin and Hitler. Analysing the dynamics of these comparisons, we can clearly see at least three peaks when the PutinHitler parallel became popular in the press [20].

The first rise in the use of the parallel was the year 2005, the year of severe Russia-Ukraine gas disputes. It was claimed in 2005 that Russia used gas supply as an oppression instrument in post-revolutionary Ukraine, where the orange revolution had taken place at the end of 2004 and led to the failure of pro-Russian presidential candidate Victor Yanukovych. The second rise began in 2007 and culminated in 2009. These years became the "Georgian" period in Russian political discourse. However, the rhetoric around the Russian intervention in Georgia was not too severe in Western media. The last increase began in 2013 with mass protests in Ukraine, and boomed in 2014 with Russia's annexation of Crimea, the autonomous republic that belongs to Ukraine. The recent Ukrainian crisis began on October $30^{\text {th }} 2013$ when Yanukovich refused to sign the EU-Ukraine association agreement. It culminated on February $20^{\text {th }}$ with mass killings of protesters in Kiev, which was followed by the Crimea annexation by Russia. The crisis continues today in three eastern regions of Ukraine, which are partly under the control of pro-Russian armed terrorists. The crisis seems to influence the existing system of international relations in general and the place of Russia within this system in particular. We can see that during the 2005 rise 947 news items that mentioned Putin and Hitler were found, while a period of less than 5 months in 2014 resulted in 2261 items. Among the top sources the items originate from are the UK and US press as well as several news agencies (Figure 2).

In order to understand the context of mentions of Putin and Hitler we checked the top subjects of the 13,039 items. The top three subjects were domestic policies; international relations and general news (Figure 3). We have to admit that some of the mentions deny the Hitler-Putin parallel (i.e. we can find 29 phrases of "Putin isn't Hitler" and 72 phrases 


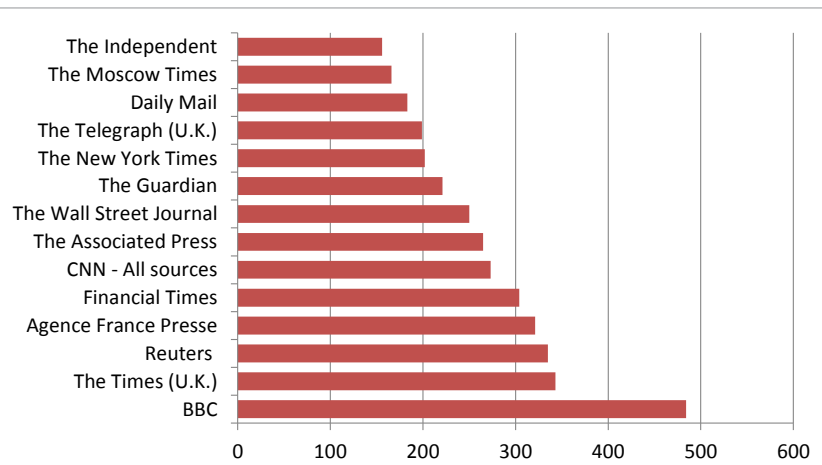

Figure 2: Top sources of Putin and Hitler mentions in English press: 01 May 2001-01 May 2014 (Data source: Factiva Database).

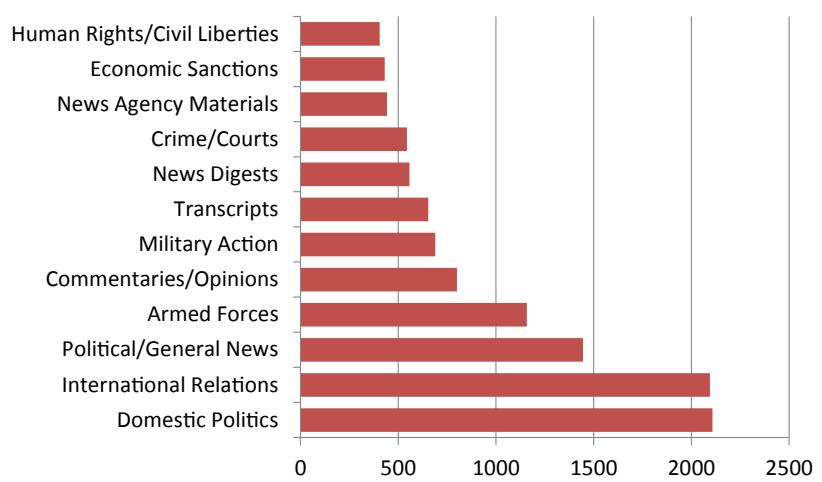

Figure 3: Top subjects of Putin and Hitler mentions in English press: 01 May 2001-01 May 2014 (Data source: Factiva Database).

of "Putin is not Hitler"), but the need for a printed denial that Putin is Hitler is still evidence of the high presence of this metaphor in the world information space.

\section{German and Spanish Media}

In the German press during the analysed period 3,258 articles in total were derived in which Putin and Hitler are mentioned in the same article. In almost half of them $(1,578)$ the two surnames were put in the same paragraph, and Hitler's surname was located within two words from Putin's 305 times. Analysing the dynamics and frequency of the Putin-Hitler metaphor in the German press we can clearly see that they repeat the line we observed in the English mass media. We can observe the same rises in 2005, 2007-2009 and a similarly considerable rise in 2014 (Figure 4).

Among the top sources the analysed metaphor originates from we can see the most influential media in Germany: Die Welt, Süddeutsche Zeitung, Der Spiegel, Frankfurter Rundschau and others (Figure 5).

The German media was chosen as a comparison to the trend observed in the English media. To confirm The Washington Post's observation that "Comparisons between Hitler and Putin are trending big time" we also checked the Spanish media space (Figure 6).

The analysis of 1,336 documents showed that the dynamics line also repeats the known scheme here-the gradual rises in 2005 and 2007-2009 and an extreme rise in 2014 (Figure 7).

As we can see, the dynamics are similar and we can suppose that similar events in international affairs influenced the frequency of mentions of Hitler in the context of Russia's policies in all three cases: English, German and Spanish.

\section{Critical Metaphor Analysis}

We can find very radical, imaginative and clearly metaphorical headlines about Putin compared to Hitler in world press. Among the most striking headlines are for example:

- Here's 'Putler:' The mash-up image of Putin and Hitler sweeping Ukraine (23 April 2014, The Washington Post)

- $\quad$ Putin, like Hitler, is an ultranationalist (28 April 2014, The Buffalo News)

- Putin's grab: "It's what Hitler did back in the Thirties" (26 March 2014, Forbes)

- Putin is no better than Hitler over Ukraine (9 May 2014 Western Daily Press)

- Is Vladimir Putin Another Adolf Hitler? (5 May 2014, Forbes)

- $\quad$ Putin's shopping list: Which country could be next? (30 April 2014, Pittsburgh Post-Gazette)

These are just a few of the headlines in which Putin and Hitler, or

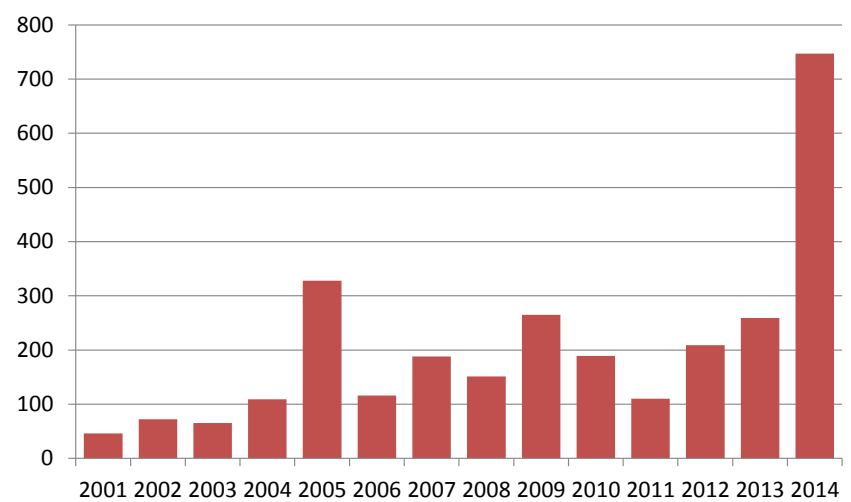

Figure 4: Putin and Hitler mentions yearly distribution in German press: 01 May 2001-01 May 2014 (Data source: Factiva Database).

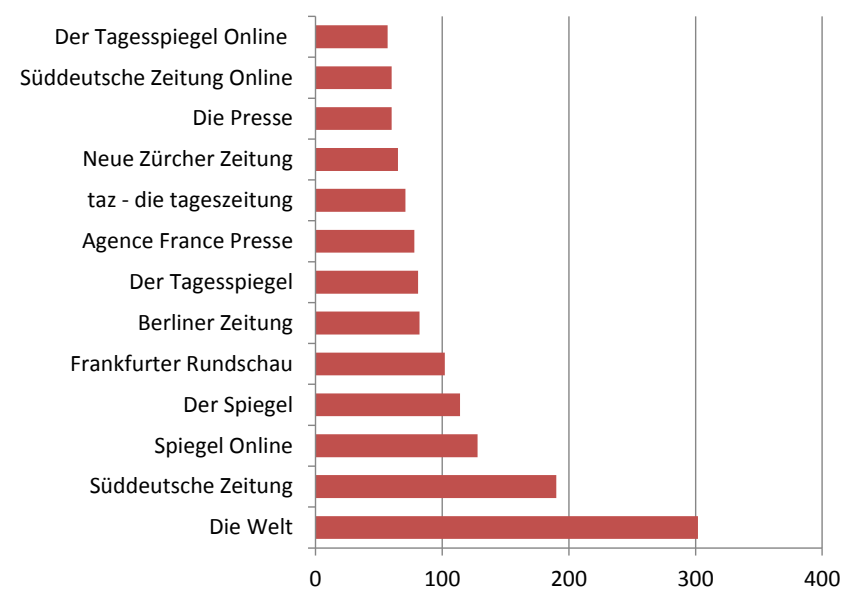

Figure 5: Top sources of Putin and Hitler mentions in German press: 01 May 2001-01 May 2014 (Data source: Factiva Database). 


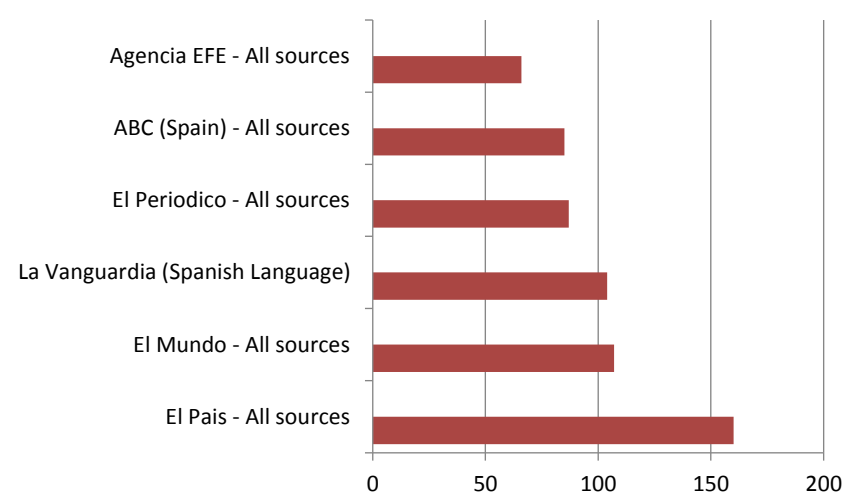

Figure 6: Top sources of Putin and Hitler mentions in Spanish press: 01 May 2001-01 May 2014 (Data source: Factiva Database).

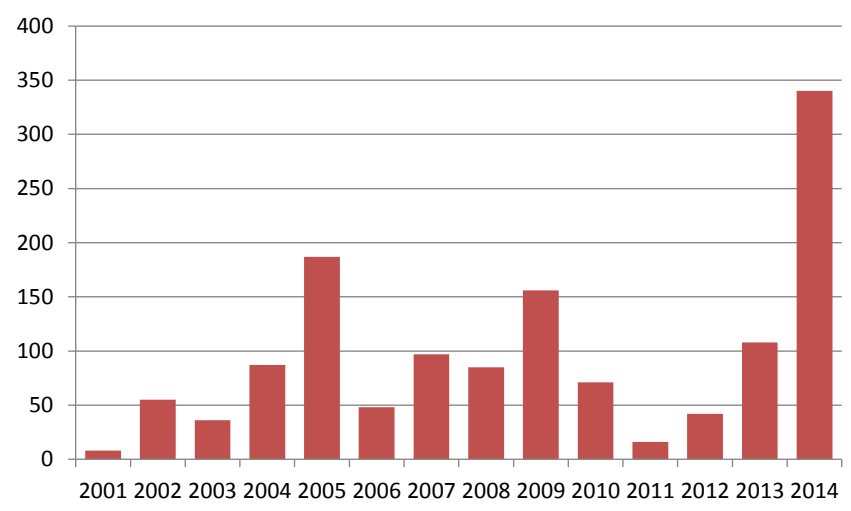

Figure 7: Putin and Hitler mentions yearly distribution in Spanish press: 01 May 2001-01 May 2014 (Data source: Factiva Database).

the threat of contemporary Russia, are mentioned. Putting such strong metaphors in a headline is a way of reaching an audience that might not be interested in reading the entire article or interview. The headlines have an affirmative nature and these few examples clearly demonstrate how powerful the metaphor can sound and how it can shape worldviews. To better comprehend the qualities of Hitler-Putin analogies in the press we chose three media sources (one American, one British and one German) and analysed all the articles in which Putin and Hitler were mentioned in the same material during the last 13 years: from May $1^{\text {st }} 2001$ to May $25^{\text {th }} 2014$. In total 268 articles were derived from The Times [21] (UK), 176 articles from The Wall Street Journal (USA) and 265 articles from Die Welt (Germany). The qualitative analysis of the articles allows us to better evaluate the context and understand the underlying meanings of the metaphors.

The Times mostly discusses the similarities and differences between Putin and Hitler in the context of comments from two public figures: Prince Charles and Hillary Clinton. The following passage from The Sunday Times by Dominic Lawson describes the context of these sayings:

"It's one of the oddities of being a member of the British royal family that an unoriginal passing remark can be elevated into an international incident. This has now happened to the Prince of Wales. On his visit to Canada he was introduced to an 87-year-old Jewish woman, Marianne Ferguson, who told him that as a child she had fled from Eastern Europe when the Nazis invaded. She then repeated to a British journalist present what the prince had said in response: "And now Putin is doing just about the same as Hitler".

Other public figures have drawn explicit comparison between President Vladimir Putin's seizure of Crimea to "protect" the majority Russian population and Hitler's annexation of the Sudetenland in 1938 to "protect" the majority German population. Hillary Clinton has said it. So has the Canadian foreign minister John Baird. In this sense, the prince was only echoing the official line of the Commonwealth government of which he was a guest" [22].

These comments served in most cases as the context for public discussion, giving a push to new metaphor applications in the media. We witness how the conceptual metaphor is being extrapolated to other features of the target domain (Putin). The Prince of Wales as well as Hillary Clinton initially compared Putin's actions to those taken by Adolf Hitler. Soon the media had widened this metaphor to Putin's arguments ${ }^{1}$, behaviour, ambitions ${ }^{2}$, language ${ }^{3}$, propaganda, plebiscite applications ${ }^{4}$, international policy in general (including Russia's diplomatic and military backing for South Ossetia and Abkhazia and also Chechnya, "his rallying cry, his Sudetenland") and Russian policy in Ukraine in particular. There is an assumption that the Hitler metaphor is taboo in Germany. "Don't mention the war" has long been the sardonic advice shared among Britons about to meet Germans. Germans have their own rule for dealing with the war and it is no joke: "Stay away from Hitler comparisons" [28]. Still, German Die Welt intensively uses the metaphor in the same contexts as The Times and The Wall Street Journal do. Die Welt discusses the words of Prince Charles and quotes German Finance Minister Wolfgang Schauble, who unleashed a political firestorm by comparing Russian President Vladimir Putin's annexation of Crimea to Hitler's seizure of the Sudetenland, then part of Czechoslovakia, in 1938. We can find the same parallels between Russia and Hitler's Germany. Opinions are normally expressed less radically on this issue but the comparison itself clearly became a public discussion in Die Welt. The metaphor is extended to the whole country, identifying contemporary Russia with Hitler's Germany:

"the elite through the installation of Putin loyalists in key posts in academia and the media, has evoked comparisons with Hitler's Germany and if a new hybrid is about to emerge from the ideological cauldron, it is almost certain to play on the idea of Russia as a bulwark against western decadence with its stand against gay rights. There are growing fears for the future of Russia's democratic institutions as Putin seeks to carve a hero's name for himself in history" [29].

Pro-Putin youth organisation Nashi is compared to Hitler Jugend "which bodes ill for Russian democracy". Another opinion leader in the UK, Stephen Fry, also stimulated public discussion in the media after

1"His (Putin's-EK) moves in Ukraine which were meant to protect ethnic Russians echoed Hitler's argument in the 1930s" [23].

2"Dmitry Medvedev's plan to build a bridge from Russia to Crimea has a long history, though not one the Russian prime minister may want to be associated with. Adolf Hitler dreamed of such a bridge in his bid to conquer Soviet Russia during World War II -- a "Golden Gate Bridge" showcasing a Nazi empire from Europe to Asia [24]. "Autobahn à la Hitler zwischen St. Petersburg und Moskau" [25].

${ }^{3}$ We can find direct citations of Hitler's and Putin's speeches on annexation: "Help was forthcoming because "no honourable great power could calmly tolerate such a state of affairs for long", as Hitler put it. Or, as Mr Putin said: "Naturally, we could not leave this plea unheeded; we could not abandon Crimea and its residents in distress. This would have been betrayal on our part" [26].

4"It was the tyrant Adolf Hitler who used plebiscites artfully mixed with massive intimidation to assert the "rights" of ethnic Germans in sundry parts of Europe in the 1930s (and finally to gain absolute power in Germany itself)" [27]. 
comparing Putin to Hitler in the context of Russia's anti-gay laws: "He [Russian President Vladimir Putin] is making scapegoats of gay people, just as Hitler did Jews. He can't be allowed to get away with it" [30]. Even those articles that aimed to refuse the idea of the identification of Putin with Hitler moved from the denial of the assumption that Putin is actually Hitler to the conclusion that some of his actions (e.g. the annexation of Crimea) are clearly "hitlery":

"Vladimir Putin is not Hitler. He doesn't shout, he's not a vegetarian, he doesn't have a tooth-brush moustache, he doesn't think Jews are vermin and he has shown no liking for Wagner. (...) there were clear parallels between Mr Putin's approach to the people and territory of his much weaker neighbours and that taken by the German dictator in the years and days before the Second World War" [26].

The last sentence of this quote illustrates another important tendency in the use of the metaphor. Hitler as a source domain for a conceptual metaphor definitely includes the threat of world war. Thus, one of the core underlying meanings of the Putin-Hitler metaphor is that the Russian leader threatens world security and stability. We can see this idea explained in a number of articles from all the sources: "We are, in effect, having a re-run of Hitler's expansion policy and the resultant appeasement that brought about the Second World War" [31]. John McCain, the US Senator, also compared Putin to Adolf Hitler during a particular period-before the Second World War: "I think he [Mr Putin] is calculating how much he can get away with, just as Adolf Hitler calculated how much he could get away with in the 1930s" [32]. The comparisons of Putin to pre-war Hitler clearly convey the message that the world community has to stop the Russian President, taking into account the fact that the global community of the 1930s failed to do this before the Second World War began. Thus, the metaphor not only expresses the threat of world war, but also calls for action and justifies the economic sanctions imposed on Russia. The Wall Street Journal is generally more radical in drawing parallels between Putin and Hitler ${ }^{5}$ than The Times, sending direct messages about Putin's policy and calling for immediate action:

"Europe stood by as Hitler swallowed Austria in March 1938 in the so-called Anschluss. The region's major powers then endorsed Germany's annexation of the Sudetenland, a German-speaking part of what was then Czechoslovakia that fall. Europe's leaders believed Hitler was entitled to the region's German-speaking territories, given their common history and cultural ties. The conventional wisdom in Europe's capitals held that allowing Germany to have Austria and the Sudetenland was a price worth paying for peace. In September 1939, however, Germany invaded Poland, triggering World War II. The lessons from Europe's appeasement of Hitler have convinced many of the region's leaders that Russia can't be allowed to keep Crimea" [33].

However, analysing the Putin-Hitler comparison as a conceptual metaphor allows us to conclude that even those articles that do not directly mention the threat of a third world war, as it is put in the above cited article, still imply this meaning in the metaphor as the figure of Hitler remains a powerful source domain for evil power threatening the existing world order, stability and peace.

\section{Conclusions}

The mass media as a powerful tool of communication assists in

5“The West Must Respond to Russia's Ukraine Invasion (headline), Mr. Putin has outdone Hitler" [34], "Mr. Putin's Russia is coming to resemble '30s-era Germany is this Orwellian doublespeak. Adolf Hitler's improbable mantra was "We want peace." Mr. Putin 's recent statements have proven equally truthful. conceptualising political views and strategies. Comparing a political leader to Hitler is one of the most powerful metaphors in a political discourse. In terms of linguistics comparing Putin to Hitler and contemporary Russia to Germany of the 1930s is a conceptual metaphor where the fascist ideology of pre-war Germany and Hitler's personality are the source domain and Russian President Vladimir Putin is the target domain. Analysing the frequency of Hitler-Putin comparisons, we can conclude that the dynamics of the use of Hitler metaphors clearly correlates with the aggressive moves of Russia in international politics (gas disputes, the Georgian conflict, the annexation of Crimea and armed support for separatist movements with features of terrorism in Eastern Ukraine). Similar dynamics and correlations can also be observed in mass media published in German (even though Hitler's personality is considered to be partly taboo in German public discourse) and Spanish. At the moment of the data collection (end of May 2014) [36] we observe the increase of the use of the Hitler metaphor in mass media published in all three languages researched: English, German and Spanish. Critical metaphor analysis of the articles derived from The Times (UK), The Wall Street Journal (USA) and Die Welt (Germany) shows that the Hitler-Putin metaphor is expanded to a wide range of issues in contemporary Russia-from antigay propaganda to plans of constructing a bridge from Crimea to Russia. The critical analysis of sample metaphors showed that explaining Putin's motives, behaviour, attitudes and style of international and internal policies in terms of those of Adolf Hitler, the mass media frames the Russian leader as a threat to world peace and security. The systematic use of the metaphor serves the legitimisation of existing political strategies towards Russia and shapes a world-view in which the Russian Federation is no longer a rising democracy, but a threat to neighbouring countries and a hypothetical threat to the existing world order.

\section{References}

1. Deirdre K (2003) Europe in the Media: A Compariosn of Reporting Representation, and Rhetoric in national Media Systems in Europe. Routledge Publishers.

2. Grimes T, Anderson J, Bergen L (2008) Media Violence and Aggression. Sage Publications.

3. Lim TS, Kim S (2007) Many Faces of Media Effects. In Mass Media Effects Research. Advances Through Meta-Analysis, London: Lawrence Erlbaum Associates Publishers.

4. Fitzgerald R, Housley W (2009) Media, Policy and Interaction. Farnhame: Ashgate.

5. Stocchetti M, Kukkonen K (2011) Critical Media Analysis. An Introduction fo Media Professionals. Frankfurt am Main: Peter Lang.

6. Matheson D (2005) Media Discourses: Analysing Media Texts. Maidenhead: Open University Press

7. Macgilchrist F (2011) Journalism and the Political. Discursive tensions in news coverage of Russia. Amsterdam: John Benjamins Publishing Company.

8. Charteris-Black J (2014) Analysing Political Speeches. New York: Palgrave Macmillan.

9. Feldman JA (2006) From Molecule to Metaphor. MIT Press

10. Ortony A (1993) Metaphor and Thought. London: Cambridge University Press.

11. Indurkhya B (1992) Metaphor and Cognition. An Interactionist Approach. Dordrecht, Springer Publishers.

12. Katz AN, Cacciari C, Gibbs Jr R, Turner M (1998) Figurative Language and Thought. New York, Oxford: Oxford University Press.

13. Turner D (2014) Putin, like Hitler, is an ultranationalist.

14. Kittay EF (1990) Metaphor. Its Cognitive Force and Linguistic Structure. Oxford: Clarendon Press.

15. Berger AA (2012) Media Analysis Techniques. Los Angeles: Sage

16. Chilton PA (1996) Security Metaphors. Cold War Doscourse from Containment to Common House. Paris: Peter Lang. 
Citation: Kuznetsova E (2014) Underlying Meanings of the Hitler Metaphor in Western Media. J Mass Communicat Journalism 4: 230. doi:10.4172/21657912.1000230

17. Beer FA, De Landtsheer C (2004) Metaphorical World Politics. East Lansing, Michigan: Michigan State University Press.

18. Walter J, Helmig J (2008) Discursive Metaphor Analysis. (De)constructions of Europe. In Political Language and Metaphor. Interpreting and Changing the World, London, New York: Routledge.

19. Shlaes A (2014) Russian Recall When Putin Evokes Stalin.

20. McCoy T (2014) Here's 'Putler:' The mash-up image of Putin and Hitler sweeping Ukraine.

21. Rankin D (2014) The Times.

22. Lawson D (2014) The Sunday Times.

23. Nicholas P (2014) U.S. News: Clinton Sets Herself to Right of Obama.

24. Torry H (2014) Crisis in Ukraine: Russian Bridge Plan Spans Troubled Past.

25. Biermann W (May 24) Wolf Biermann: Putin fürchtet den Volkshunger nach Freiheit.
26. Aaronovitch D (2014) Charles is right about Putin. So let him speak.

27. Lawson D (2014) Putin is Punch and Merkel is Judy. Who'll play the policeman? 28. Karnitsching M (2014) World News: Minister Trips on German Taboo With Hitler Remark.

29. Campbell A (2014) Wells slams plan to boycott Winter Games over anti-gay laws.

30. Campbell M (2014) Rise of the New Russian Empire.

31. Lawson D (2014) Russian expansion is a challenge for the West.

32. Karim F (2014) White House: Russia may invade eastern Ukraine.

33. Karnitschnig M (2014) Land Grab Sparks Wartime Allusions.

34. Kalinski P (2014) The West Must Respond to Russia's Ukraine Invasion.

35. Kasparov G (2004) Say It in Russian: 'Caveat Emptor'.

36. Chater D (2011) Viewing Guide. 